\title{
The Humanism of Segun Ogungbemi: His Journey to the Vision of Openness
}

\author{
TAIWO, Olusegun Stephen \\ Department of Philosophy \\ Adekunle Ajasin University \\ Akungba-Akoko, Ondo State \\ Nigeria
}

\begin{abstract}
This paper examines the philosophical dexterity of Segun Ogungbemi in order to articulate his ideology as one that portrays humanism as a philosophical doctrine. Segun Ogungbemi in his philosophical disquisitions profoundly distorts and refutes some religious beliefs and metaphysical assumptions that could not be graphically established. To achieve our aim, the paper shall have a general understanding of what humanism. The paper reflects on some thoughts of Ogungbemi as articulated in some of his philosophical discourses that reflect humanist thought. The humanism of Ogungbemi is based on his liberal disposition to knowledge which he writes out of his personal conviction about the idea he canvasses. His disposition unarguably leads to fecundity of ideas and knowledge in the ever-increasing multidisciplinary environment.
\end{abstract}

Keywords: Segun Ogungbemi, humanism, humanities, African Traditional Religion.

\section{Short Biographic Note}

Taiwo, Olusegun Stephen teaches Philosophy at Adekunle Ajasin University. His area of interest is in African Womanism, Existentialism, Ethics and African Philosophy.

\section{Introduction}

The impetus to write this paper comes from the inspiration and advice of Mary E. Modupe Kolawole in her paper titled "Literature and Sustainability in the Age of Technology" at Adekunle Ajasin University, Akungba-Akoko for the Nigerian Academy of Letters Annual Lecture 2011. She posits inter alia that: The world will always need the humanities to humanise it. A Yoruba proverb relevant to the dilemma of social change says 'agbaraojokoniohunkoniwo 'le, onileni o nigba fun' meaning the flood does not mind demolishing the house, but the owner will not allow it. The African writer must not allow social change or technological advancement to destroy the impact of culture. One way of sustaining culture especially literature, is to adopt technology and adapt it. ${ }^{1}$ (Kolawole, 2011:2)

The admonition for African writer is what I want to showcase to salute the courage and humanism of Segun Ogungbemi. By humanism, I mean the philosophical and ethical stances that Ogungbemi took which emphasize the value and agency of human beings. Furthermore, I extend humanism to mean a most human philosophy of life. The paper vigorously examines the philosophical dexterity of Segun Ogungbemi in order to articulate his ideology as one that portrays humanism as a philosophical doctrine. Segun Ogungbemiin his philosophical disquisitions profoundly distort and refute some religious beliefs and metaphysical assumptions that could not be graphically established. He often refers to such beliefs as enigma that rational minds grapple and contend with. For his philosophical attitudes and interpretations of African worldview, one finds it difficult to locate the best doctrine under which his philosophical analysis could be classified. This reflects the fact that his postulations, though anti-Christian in nature, does not mean he is a staunch atheist neither could he be considered as a theist because of his doubts about the attributes of a religious God in the presence of challenges in contemporary society; yet, he eulogizes the efficacy of some Yoruba traditional deities in Yoruba traditional religion. Ogungbemi sets the springboard of his philosophical humanism on his rejection of the biblical creation story which he considered as a myth. He argues that "no man called Adam, or a woman called Eve, ever lived. The word 'Adam' means man and the word 'Eve' means woman. The 'genetic sin' of Adam, scholars argue, is counter-intuitive and morally unjust if taken literally. Scientists have also argued that the universe created by God has no purpose."2(Ogungbemi, 2007:160). This thought, as pointed out by Ogungbemi, makes him set some criteria which he considered as minimal to include: God's appearance must be public and universal rather than private and individualistic; all the omni... attributes of God should be discountenanced; the universality of the existence of God must be indubitable in any form of linguistic description; and the moral principles of God must be such that they enhance the well-being of humans rather than worsen their condition either here on earth or in the hereafter, assuming there is immortality. 
Humanistically, Ogungbemi assumed that given the preponderance of uncertainty that trailed the universe and the idea of God's existence, "it is not credible to believe in His existence. It is rather better to be an existential agnostic onlooker in a world crippled with religious uncertainty and deceit"3 (Ogungbemi, 2007-2008:13). It is from this perspective that this paper reflects on some thoughts of Ogungbemi as articulated in some of his philosophical discourses that reflect humanistic thought. The humanism of Ogungbemi is based on his liberal disposition to knowledge which he writes out of his personal conviction about the idea he canvasses. His disposition unarguably leads to fecundity of ideas and knowledge in the ever-increasing multidisciplinary environment. ${ }^{4}$ (Igboin, 2006:25). It is however pertinent to have a general understanding of what humanism is before delving into Ogungbemi's analysis.

\section{The Meaning of Humanism}

Humanism is an ageless philosophy of life that contributes to the development of humanity, regardless of place and/or time. It has competed with other ideologies as the human way of viewing and explaining reality beyond metaphysical and spiritual assumptions. Humanism gives meaning to life and helps to find an understanding of human's place in the society and indeed, the universe. Humanity is eternally compelled to be nothing else than human. Humanity is its own burden. Humans did not come to this world with technology, science or humanity, it is while here we jointly co-create society, philosophy, arts, history, values, laws, community, technology, science, humanity, etc.Thus, Bernard Smoker conceives humanism as "a worldview that is purely secular and scientific in outlook." (Bernard, 2006:1). By implication, it is a philosophy that sets at its center stage the condition of human beings in this natural world, and their pursuit of happiness and fulfillment. It is in this perspective that humanism, according to Lamont literally means 'human- being-ism." (Lamont, 1997:17)

It is germane to mention that for ages, past humanity has always been confronted with the challenges of how to live meaningfully within the polarities of existence in the world beclouded with ups and down, that is, contradictions. In solving this reality, several belief systems have been formulated throughout human history, all in a way to proffer solutions to the challenges of making human experiences livable in the world. It is fathomable from the analysis of what humanism connotes that its peculiarity lies in the fact that it strongly believes that the only way to enrich our existence in this world is through human effort alone without recourse to any higher forces either natural or supernatural. It is within this purview that NkeonyeOtakpor's conception of humanism as a doctrine that presupposes "to live by human means, without gods, God or divine help"" (Otakpor, 2008:69) is considered apposite. While for Moses Makinde; the humanities accept the existence of mind and body, or the mental and the physical, science accepts only the existence of matter or the physical by claiming that science can only deal with intangible, inexperienced and inexperienceable mental events that are not subject to scientific explanation and prediction ... From this point of view science is detached from the study of any subject that involves the phenomenon of the human mind such as we find in the humanities which are concerned not only with humanity in general, but also with the way people think and behave in the society. ${ }^{8}$ (Makinde, $2008: 37$ )

It follows, therefore, that humanism could be construed as a philosophy that portrays human beings as the determinant of their worldview devoid of any form of scientific manipulation of human mind. This shows the relationship between humanism and humanities. Given the foregoing, humanism presupposes a philosophical outlook that cogitate the dignity and freedom of human beings. This position conforms to G.E. Idang's conception of humanity as "a philosophical outlook that is centered on the autonomy of man as a dignified, rational being who is thought of as possessing within him the source of truth and light." (Idang, 2015:125). It is important to mention that humanism could be philosophically discussed within the purview of metaphysics, theory of human personality, ethics and epistemology. However, delving into this is a subject of another discourse entirely. Nevertheless, it is necessary within the context of the current engagement to give a brief explanation of humanist theory of human personality. This is because it is pivotal to Ogungbemi's conception of humanism. Also, it reflects the physicalism of humanism that bears many implications on its conception of human personality that affirms the non-existence of supernatural entities that suggest human beings as wholly material beings. Lamont puts it as "a unity of body and personality," (Lamont, 1997:88) where body could be understood to mean "the whole physical structure of a human or an animal"11 (Hornby, 2005:153).

Personality is definable as "a fluid, developing complex of habits, impulses and ideas that is never finished and is always in the making through its activities and interests." ${ }^{12}$ (Lamont, 1997:268). This implies that the humanistic conception of human personality is monistic, that is, wholly material rather than dualistic. The monistic idea of human personality is well echoed in Ogungbemi's humanism where such a belief in transcendentalism is considered absurd as reflected in his conception of death as that which ends human existence without any link with hereafter or after-life existence: In his words, "nature has made death the means of exit for all living things, including human beings"13 
(Ogungbemi, 2008:109). The implication of Ogungbemi's position within the confines of this discourse suggests death as an end in itself and not a means to an end as pictured in the theistic idea of immortality.

\section{Ogungbemi's Humanism in Perspective}

Ogungbemihas been exposed to countless cultures - Yoruba, Hausa, Western, etc; so also to religious belief across the globe such as Christianity, African Traditional Religion which has helped him to define his own beliefs in Yemoja (goddess of Water) and Ogun (god of Iron, war, peace and justice). He blesses anybody who cares to say ase meaning amen by saying Yemoja a fun yin niomi meaning Yemoja would give you water; Ogun a gbe yin o meaning Ogun blesses you, Irunmole a tun tie se meaning Irunmole would make a way for you. Ogungbemi's belief in Ogun and ancestral world is a recognition of the inherent values in their traditions. The values are honesty and sincerity in the tenet and worship of Ogun. ${ }^{14}$ (Taiwo, 2006:136). To a Christian, Ogungbemi is a non-believer not only in the sense that he believes in Ogun but also because he conspicuously challenges Christian thought. Ogungbemi himself thinks other might misinterpret him as anti-religious or pure atheist. ${ }^{15}$ (Ogungbemi, 2006:15). Some point out that Ogungbemi is not a hard atheist. We may suspect him to be a weak atheist or an agnostic-existential onlooker. ${ }^{16}$ (Igboin, 2006:25). Though when benediction is said he joins reverentially. Despite his atheistic posture to a religious God, he usually prays in the name of Olodumare. It is in the light of this presupposition that one could not outright pin him down to be a thorough breed atheist, hence the assumption and observation that he best qualifies as a humanist in the real sense of it. I witnessed one day where both of us went to the burial of his age mate though senior to the person. He was called to pray as the most senior person. He prayed in Olodumare's name. He is not a Christian as a believer in Jesus Christ but he quotes the scriptures because he was sponsored for the postgraduate studies in Philosophical Theology and Ethics at Perkins School of Theology, Southern Methodist University, Dallas, Texas, U.S.A.

\section{SegunOgungbemi: the early years and the journey to openness}

Before joining the Adekunle Ajasin University, Akungba-Akoko in August 2004, Ogungbemi had given lectures in Philosophy to many students. These schools include among others Bishop College Dallas, Texas, in the United States of America, Ogun State University, Ago-Iwoye now OlabisiOnabanjo University, Ogun State; Moi University, Eldoret, Kenya and Lagos State University, Ojoo, Lagos State. He has also engaged in serious research in Theology and Philosophy. He gave the following lectures and papers in the United States of America; they are: "A Philosophical Reflection on the Religiousity of the Traditional Yoruba", "The Spirit of Pan-Africanism and Nationalist Consciousness: The Way Forward in the 21st Century", "Faith and Reason in Nigeria's Religious Space", "The Challenges of Boko Haram Insurgency and Development in Contemporary Nigeria", "African Women at the Receiving End", "Esu: the Phenomenon of Existence", "A Philosophical Analysis of Yemoja in Cross Cultural Context" among others. The paper titled "The Spirit of Pan-Africanism and Nationalist Consciousness: The Way Forward in the 21st Century" earned him a distinguished Award for the Advancement of Pan-African Dialogue at the 2014 African Conference held at the University of Texas at Austin, United States of America.

It was at Akungba-Akoko University that Ogungbemi could be termed a liberal in his accommodating critical views from colleagues which was put in a book titled God, Reason and Death - Issues in Philosophy of Religion. About six contributors with diverse opinions reacted to Ogungbemi's papers 'Belief in God' and 'Death: A Moral Issue'. Ogungbemi opens his argument on the belief of God which needs for him a rational scrutiny in order to ascertain their empirical and metaphysical warrants. The search for justification of religious beliefs is necessitated by our understanding of the universe in modern times, due to development in science and technology which have made it necessary to re-examine our fundamental beliefs, however cherished they may be. ${ }^{17}$ (Ogungbemi, 2006:15) Ogungbemi provides concrete examples to drive home his arguments. From this Ogungbemi takes us back to the question of the contribution on the burden of arts, humanities and social science in favour of science and technical disciplines. My answer is that humanity would still need to humanise the world and we need to adopt and adapt the gains of science and technology to arts, humanities and social science as a tool to further humanise the world.

On 'Death: A Moral Issue', Ogungbemi's compelling need is to consider the moral challenge death poses. He concurs to philosophical counsel of Rang'inya that death is a necessity for man so that the natural environment can be decongested of human population. Thus death is a potent method of controlling population of both humans and habitants; and the distribution of natural wealth and resources.

\section{Rationality and African Traditional Religion: A Case for Ogungbemi Humanism}

Ogungbemi's consciousness of the importance of philosophy and concern for the personal, social and intellectual development of humanity based on rational inquiry invigorates the necessity to put African traditional religions under the microscope of reason just as other religions of the world passed through it. He explains that: African Traditional Religion is the religion of our African forebears which is passed from one generation to another. 
Some of the beliefs in this religion are, God, divinities, spirits, ancestors, and the place of man in the universe, worship, rainmakers, medicine men and women, witchcraft, sorcery and magic, initiations, morality, death and immortality. The religion does not need any recognition from outside, since the religion does not require a wholesale evangelisation outside its environment. Defending its faith is not its uttermost priority. The religion is practised as a matter of course regardless of Western prejudices. ${ }^{18}$ (Ogungbemi, 1997:24).

Two issues are germane to Ogungbemi. These are the practice of the religion by Africans and the teaching of the discipline in our various institutions in Africa. To the practice of the religion by Africans, "shrines in most cases appear to be immune to modern hygiene. The modes of worship remain esoteric. The believers in African indigenous religion ignore modern developments which we see around, for instance, building of local Churches and Mosques would probably impress the divinities." ${ }^{, 19}$ (Ogungbemi, 1997:25).Furthermore, the adherents of African Traditional Religion should "encouraged international evangelistic approaches like their counterparts in Christianity and Islam, they would have learnt from the development of other countries and used the knowledge to enrich their societies." ${ }^{20}$ (Ogungbemi, 1997:25).

The teaching of African Traditional Religion for Ogungbemi is uncritical because of recourse to apologetic works of Parrinder, Idowu and Mbiti that are not critical to mention these three. We need more critical works which I believe we have so many books now. I could count YemiElebuibon, Jacob K. Olupana, Awolalu J. Omosade, P. Ade Dopamu, Kola Abimbola, Wande Abimbola, among other.

Giving recognition to this necessity, Ogungbemi in one of his philosophical discourses titled "Yoruba Traditional Religious Belief System" seems to have modified his contribution to humanism by quoting Awolalu (1998:116) that "the Ifa Temple at Ile-Ife, for example, is a huge edifice situated on Oke-Itase Hill overlooking the city. The huge building compares favourably with any cathedral church in size. Similarly, the Osun shrines in Osogbo have been remoulded by Susanne Wenger, a European artist who has accepted traditional religion and who has become a devotee of a number of divinities worshipped in Yorubaland, particularly Osun and Sango."21 (Olupona, 1998:116).The reference to this could be considered as a way of checking out the uncritical and crude means of traditional worship. And since humanism is all about humanity and development, it is, therefore, suggestive that Ogungbemi to an extent gives credence to this innovation as new development.

In another paper titled "A Philosophical reflection on the Religiosity of the Traditional Yoruba", Ogungbemi argues that there is a strong egoistic and practical motif in Yoruba culture that has not been hitherto emphasised. Although the belief system of the traditional Yoruba may appear other-worldly and even excessively religious to religious and secular minded observers alike, the egoistic and practical dimension is pervasive. Religion is employed as a means to legitimise individual and social needs and achievements. ${ }^{22}$ (Ogungbemi1986:61). The idea discussed here is the sets of values the Yoruba man/woman makes as a detour to religion. Ogungbemi believes "some ethno-philosophers like E. BolajiIdowu, J. Omosade Awolalu and J.S. Mbiti that have written about Yoruba beliefs and culture, have overemphasised the importance of religion to the extent that one can hardly see any values in Yoruba culture from religion. ${ }^{23}$ (Ogungbemi, 1986: 61-62). As such, Ogungbemi presents a humanistic interpretation of the Yoruba thought on human existence that is more profoundly expressed in their social and moral values, which are basically the pursuit of existential needs which are human-centered instead of God-centered. He is of the view that the Yoruba should be courageous and rational in confronting the paradoxes of life instead of seeking refuge and/or escape root in religious beliefs.

This is pungently revealed in his assumption that some Yoruba that abandoned their gods and took to Christianity or any other religion did so for material gains of modern medicine, education and technology to provide a better solution to their needs than the metaphysical power of deities. Thus, human reason overruled their dogmatic beliefs in such metaphysical power that could be arguably portrayed as hindrances to human development before the age of enlightenment. The search for meaning of life in the face of reason in his view therefore creates a religious/cultural identity which could be captured as 'African problematic' as it relates to religious/cultural identity. Olusegun Oladipo posits that: a poignant portrait of the process of loss of personality by the African elite, which brought the problem of self-definition to the centre of African scholarship in the 1950s and the 60s. This made Africa in the first place not being able to reconstruct her societies in a manner that can empower her people to realise their human potentials in significant manner. Secondly, Africa has failed to achieve cultural rebirth that can ensure that her encounters with other cultures are mutually enriching rather than socially destabilizing. ${ }^{23}$ (Oladipo, 2009:2,8)

These apply to the religious/cultural identity. In a similar line of argument, Akinwumi Isola opines that: the fatal effects of interventions like the slave trade, colonialism and two foreign religions overwhelmingly undermined the development and progressive capacities of African culture .... 
The privileged ruling elites which are product of the educational systems cannot lead the journey back to values in our cultural heritage because...their curricula were tailored to achieve the goals of the coloniser rather than the colonised to be independent .... While the rest of the people, the abandoned majority, took notice, felt disturbed, but could only look on. $^{24}$ (Isola, 2010:3)

Upon critical reflection, it is apparent from the above that Africans need a rigorous re-examination of their worldview to meet up with the challenges that are poised by the contemporary realities. This is not unconnected with the fact that those that are viably inclined with the original traditional African worldview are no longer in existence. Aside this reality, the need to adopt a middle line course in the era of positive aggressive globalisation and modernisation calls for the adoption of humanistic principles that rely so much on human rationality as espoused in some of Ogungbemi's philosophical thoughts examined in this paper. It is within this purview that Ogungbemi's criticism of some African beliefs is considered valid, though without escaping the "fallacy of clash of culture". Nevertheless, one cannot holistically reject his positions as meaningless. That would be against the essence of humanities as articulated in the report of the commission on the humanities which "aims to show that the activities of mind are not geometric proof and quantitative measure, but rather insight, perspective, critical understanding, discrimination, and creativity." ${ }^{25}$ (The Humanities in American Life, 1980:2). Thus, one is poised to examine Ogungbemi's humanism in the light of the understanding of ethics, science and technology. This forms the onus of the next aspect of this discourse with a view to further showcasing Ogungbemi's humanistic approach to existence.

\section{Ethics, Science, Technology and Humanism of Ogungbemi}

Science and Technology, as some scholars have argued, brings about quick money-value. This is so because generally speaking, science and technology has improved human transportation, education, industries, communication and information dissemination, employment, security, population, agriculture, energy, health, longevity etc. We can affirm that the world as we know it today is better than some centuries ago. But the truth of the matter as Ogungbemi a true humanist says is that a small fraction of the world population has the largest share of the apple pie of technology. He uses Charles Hartshorne's argument that "technology, besides making it possible for larger numbers to enjoy the goods of life, makes it possible for an additional huge numbers to live at marginally, and even marginal living is better than nothing. The will to live may be sustained by minimal satisfactions, but they are still satisfactions. In sum, technology has greatly enlarged three groups of people, those with minimal, mediocre, or optimal modes of living, to buttress his point." 26 (Hartshorne, 1980:70)

If those with minimal satisfactions and the mediocre as explained by Hartshorne share the benefits of technology equally with those of optimal mode of living, what will happen to human environment? Or in another sense, if the human beings are using the energy resources of the world, what types of ethics should be applied? In both senses, Ogungbemi reminds humanity that there is need to adopt the African traditional environment ethics which teaches not to take more from nature than what is needed. The environment principle is called "Ethics of nature-relatedness" or "Ethics of care." The question of how do we know how much we need considering human nature of greed and who judges whether we have taken more than we need from nature are answered by both human conscience and the principle of common sense guided by reason, experience and the will. The Ethics, according to Ogungbemi, encourages human beings to take a cooperative attitude to nature and to co-exist peacefully with it, bearing in mind that it is from nature that they derive nurture, growth, survival and sustainability. ${ }^{27}$ (Ogungbemi, 2010:11)

\section{Conclusion}

So far, what I have done is to argue that Ogungbemi has contributed to the development of humanity. He shows the values of humanities by his openness to people of diverse religions and cultures. While promoting his personal convictions, he does not force you to change to his belief neither is he expecting you to convert him to any religion. What to be believed will depend on the individual. His love to ask questions concerning any religion, and particularly Christianity and African Traditional Religion does not make him an atheist or a theist but an admirer of inherent values of honesty and sincerity both in the intra and interpersonal relationship for the survival of humanity.

If we do not talk about ethics in science and technology, a lot of nonhuman living creatures on this planet would not be enlarged even as science and technology profess. As Charles Hartshorne observes "where dead concrete is now, myriads of living species once flourished; where a few species of grains and a few sorts of animals requiring forest, swamp, or wild prairie once enjoyed their lives in their own nonhuman way."28 (Hartshorne, 1980:70). What should humanists, ethics or philosopher do? The answer lies in what Walter H. O'Briant says "we shall have to write a new ethics and re-orient ourselves to a quite different world. We really have no choice if man and nature are to thrive." ${ }^{29}$ (O’Briant, 1980:89). 
Humanists, ethicists or philosophers are to provide moral principles or ethical theories to humanise humanity. Though technology had the capacity for development, the society needs the full complement of humanity to effect true change. When technology was development driven, it was humanity that would test its usage.

\section{Notes}

1. Mary E. ModupeKolawole, 2011, "Literature and Sustainability in the Age of Technology." Guest Lecture delivered at Adekunle Ajasin University Akungba-Akoko for the Nigerian Academy of Letters Annual Lecture.

2. SegunOgungbemi, 2007,Philosophy and Developments, (Ibadan: Hope Publications).

3. SegunOgungbemi, 2007-2008, "Beliefs in God: A Philosophical Analysis", Orisun: Journal of Religion and Human Values, 6 \& 7 .

4. Benson O. Igboin,2006,A Response to 'Belief in God'", SegunOgungbemi (ed.) God, Reason and Death: Issues in Philosophy of Religion,(Ibadan: Hope Publications).

5. Bernard Smoker, 2006, Humanism, (New York: Gadfly Publishers

6. Clement Lamont, 1997,The Philosophy of Humanism, (New York: Humanist Press).

7. NkeonyeOtakpor,2008,"Secularism, Humanism and God",SegunOgungbemi(ed.)God, Reason and Death: Issues in Philosophy of Religion,(Ibadan: Hope Publications).

8. Moses Makinde, 2008, "The Humanities and Good Governance: A Philosophical Appraisal”, being a paper presented at the 10th Annual Convocation of the Nigerian Academy of Letters, University of Lagos, The Nation, Thursday, October 30.

9. G.E. Idang, 2015, On Humanism and Morality.Sapentia: Journal of Philosophy, 5.

10. Clement Lamont, 1997, The Philosophy of Humanism.

11. A.S. Hornby,2005,Oxford Advanced Learner's Dictionary.Oxford: Oxford University Press.

12. Clement Lamont, 1997,The Philosophy of Humanism.

13. SegunOgungbemi, 2006,"Death: A Moral Issue",God, Reason and Death: Issues in Philosophy of Religion, (ed.),SegunOgungbemi, (Ibadan: Hope Publications).

14. OlusegunTaiwo, 2006, "In Defence of Christianity: Wittgensetin to the Rescue", God, Reason and Death: Issues in Philosophy of Religion, (ed.),SegunOgungbemi.

15.SegunOgungbemi, 2006,"Belief in God",God, Reason and Death: Issues in Philosophy of Religion, (ed.),SegunOgungbemi.

16. Benson O. Igboin,2006,A Response to 'Belief in God"', SegunOgungbemi (ed.) God, Reason and Death: Issues in Philosophy of Religion.

17.SegunOgungbemi, 2006,"Belief in God",God, Reason and Death: Issues in Philosophy of Religion, (ed.),SegunOgungbemi.

18. SegunOgungbemi, 1997,A Critique of African Cultural Beliefs, (Lagos: Pumark Educational Publishers).

19.SegunOgungbemi, 1997,A Critique of African Cultural Beliefs.

20. SegunOgungbemi, 1997,A Critique of African Cultural Beliefs.

21. Omosade J. Awolalu, 1998, African Traditional Religions in Contemporary Society, (ed.), Jacob K. Olupana, (Minnesota: Paragon House).

22. SegunOgungbemi, 1986, "A Philosophical Reflection on the Religiosity of the Traditional Yoruba", Orita: Ibadan Journal of Religious Studies, XVIII/2 December.

23. OlusegunOladipo, 2009,Philosophy and Social Reconstruction in Africa,(Ibadan: Hope Publications).

24.IsolaAkinwumi, 2010,Making Culture Memorable: Essays on Language, Culture and Development, (eds.), OlusegunOladipo and DuroAdeleke, (Ibadan: Hope Publication).

25. Report of the Commission on the Humanities, 1980, The Humanities in American Life, Berkley: University of California Press.

26. Charles Hartshorne, 1980, “The Environment Results of Technology”,(ed.), William T. Blackstone,Philosophy and Environment Crisis. Athens: University of Georgia Press.

27. SegunOgungbemi, 2010, "Modern Science and Technology in Conflict with African Environmental Ethics," Caribbean Journal of Philosophy, 2:1.

28. Charles Hartshorne, 1980, "The Environment Results of Technology".

29. Walter H.O'Briant, 1980, "Man, Nature and the History of Philosophy", (ed.), William T. Blackstone,Philosophy and Environment Crisis. Athens: University of Georgia Press. 


\section{Bibliography}

Blackstone, T. William.(Ed.). Philosophy and Environment Crisis. Athens: University of Georgia Press. Hornby, A.S. (2005). Oxford Advanced Learner's Dictionary. Oxford: Oxford University Press.

Idang, G.E. (2015). On Humanism and Morality.Sapentia: Journal of Philosophy, 5,.

Kolawole, M. E.M. (2011). Literature and Sustainability in the Age of Technology. Guest Lecture delivered at Adekunle Ajasin University Akungba-Akoko for the Nigerian Academy of Letters Annual Lecture.

Lamont, Clement. (1997). The Philosophy of Humanism, New York: Humanist Press.

Olupona,KJacob.(Ed.) (1998). African Traditional Religions in Contemporary Society.Minnesota: Paragon House.

Ogungbemi, Segun. (1986). A Philosophical Reflection on the Religiosity of the Traditional Yoruba", Orita: Ibadan Journal of Religious Studies, XVIII/2, December..(1997). A Critique of African Cultural Beliefs. Lagos: Pumark Educational Publishers.

. (2007). Philosophy and Development, Ibadan: Hope Publications.

. (2007-2008). Belief in God: A Religio-philosophical Analysis.Orisun: Journal of Religion and Human Values. 6 \& 7 , (Ed.).2006. God, Reason and Death: Issues in Philosophy of Religion.

Ibadan: Hope Publications.

. (2010). "Modern Science and Technology in Conflict with African Environmental Ethics".Caribbean Journal of Philosophy, 2:1.

Oladipo, Olusegun.(2009). Philosophy and Social Reconstruction in Africa.Ibadan: Hope Publications.

Oladipo, Olusegun and Adeleke, Duro. (Eds.)(2010).Making Culture Memorable: Essays on Language, Culture and Development. Ibadan: Hope Publication.

Report of the Commission on the Humanities. (1980).The Humanities in American Life, Berkley: University of California Press.

Smoker, Bernard.(2006).Humanism.Ibadan: Gadfly Publishers. 